Vietnam Journal of Mechanics, VAST, Vol.30, No. 2 (2008), pp. $99-111$

\title{
RESEARCH ON MANUFACTURING DRY MIXED CEMENT MORTAR WITH HIGH COMPRESSIVE STRENGTH, HIGH FLEXURAL STRENGTH, LOW SHRINKAGE AND HIGH WATERTIGHTNESS FOR RESTORATION OF DAMAGED HYDRAULIC STRUCTURES IN VIETNAM
}

\author{
Nguyen Quang Phu ${ }^{1,2}$, Hoang Pho Uyen ${ }^{3}$, Jiang Lin Hua ${ }^{1}$, Liu Jiaping ${ }^{4}$ \\ ${ }^{1}$ College of Materials Science and Engineering, \\ Hohai University, Nanjing, P.R. China (210098) \\ ${ }^{2}$ Faculty of Hydraulic Engineering of Water Resources University, Vietnam \\ ${ }^{3}$ Research of Building Material Science Department, \\ Institute of Water Resources Research, Vietnam \\ ${ }^{4}$ Jiangsu Research Institute of Building Science, Nanjing 210008, China.
}

\begin{abstract}
Using normal materials to manufacture the mixed mortar is necessary for restoration of hydraulic structures in Vietnam. It will salvage the materials and decreases the cost price of the mortar. In this research, we used cement made in Vietnam (Chinfon - Haiphong cement), natural sand (Lo River sand), polymer acrylic and high range water reducing (of SIKA company) with proportion $1: 3: 0.03: 0.003$ by weight. The water to cement ratio is 0.5 , which always ensure the compressive strength of mortar more than $40 \mathrm{MPa}$ and small shrinkage, good watertightness, and high adhesion. That is suitable for the restoration of concrete structures in general and hydraulic structures in particular of Vietnam. The dry mixed mortar is manufactured and in bag of $15 \pm 0.5 \mathrm{~kg}$ weight.

Keywords: dry mixed cement mortar, compressive strength, shrinkage, flexural strength, adhesion, watertightness, high range water reducing admixture (HRWR), polymer acrylic.
\end{abstract}

\section{INTRODUCTION}

After fifty years, many hydraulic structures in Vietnam were damaged and downgraded that why it is necessary to repair them for continuing operated. Here the most important hydraulic structures are made of concrete and reinforced concrete, that when repairing has required the same materials having the same fundamental properties. In order to repair those structures, the mortar from cement with high compressive strength, no shrinkage, and high watertightness is used [1].

The mixed mortars have good properties of some overseas companies are available in Vietnam, but they are very expensive, so they are not suitable for Vietnam situation. Actually, the materials needed to manufacture these mortars are available in Vietnam and we can use them to make a kind of mixed mortar using to repair the damage of structures in general, hydraulic structures in particular. To produce this mixed mortar we can use usual materials Vietnam's. 


\section{RESEARCH OBJECTIVES}

The objective is to manufacture the mixed cement mortar which has high compressive strength, high flexural strength, low shrinkage and high watertightness in order to repair hydraulic concrete structures and reinforced concrete structures. The mortar should have following properties:

+ High watertightness

+ Good slump for application

+ The good adhesion with the parent concrete and mortar

+ High compressive strength $\left(f_{c}^{\prime} \geq 40 \mathrm{MPa}\right)$.

\section{MATERIALS}

\subsection{Cement}

Chinfon Portland cement PC 40 made in Hai Phong, Vietnam. Its physical properties are shown in Table 1

Table 1. Physical properties of Portland cement PC40 Chinfon - Haiphong

\begin{tabular}{|c|l|l|l|}
\hline $\boldsymbol{N}^{\mathbf{O}}$ & Item & Unit & Result \\
\hline 1 & Compressive strength, 28 days & $\mathrm{MPa}$ & 42 \\
\hline 2 & Flexural strength, 28 days & $\mathrm{MPa}$ & 6.0 \\
\hline 3 & Setting time: Initial;Final & minute & $113 ; 190$ \\
\hline 4 & Specific gravity & $\left(\mathrm{g} / \mathrm{cm}^{3}\right)$ & 3.10 \\
\hline
\end{tabular}

\subsection{Fine aggregate (sand)}

In this research, we used the standard sand and the crush silicon sand. The results were very good, but the cost price was very high, therefore we have taken the river sand for experiments [2]. Namely, we used Lo River sand which has some properties as shown in Table 2.

Table 2. Properties of fine aggregate (sand)

\begin{tabular}{|c|l|l|l|}
\hline$N^{\circ}$ & Item & Unit & Result \\
\hline 1 & Bulk specific gravity on oven-dry basis & $\left(\mathrm{g} / \mathrm{cm}^{3}\right)$ & 2.65 \\
\hline 2 & Apparent specific gravity & $\left(\mathrm{g} / \mathrm{cm}^{3}\right)$ & 1.45 \\
\hline 3 & SSD $^{*}$ Absorption & $\%$ & 0.4 \\
\hline 4 & Fineness modulus & & 2.54 \\
\hline \multicolumn{2}{|c|}{ SSD $^{*}:$ Saturated surface-dry } \\
\hline
\end{tabular}

The sand is sieved to reject the grains size $>5 \mathrm{~mm}$. Then it was dried by the oven in temperature of $100-150^{\circ} \mathrm{C}$ for five hours until the humidity of sand equal zero percent. The sand was packed and kept in the dry condition.

\subsection{Polymer}

Polymer acrylic is admixture in form of powder, dry, white color, odorless. It is easy to dissolve in the water. The chemical function of Polymer acrylic as shown following [3]: 


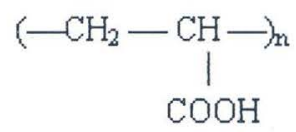

\subsection{High range water reducing admixture (HRWR)}

High range water reducing admixture has the brand name of Mighty [3]. The main component of Mighty is naphthalene formaldehyde sulphonated. This admixture is being sold in Vietnam.

\section{MIXTURE PROPORTION}

\subsection{Design preliminary proportion mortar}

The mortar using in concrete structures and reinforced structures must have high compressive strength (the compressive strength of mortar and the compressive strength of mortar matrix in old concrete is equivalent). However, the polymer mortar has not strength function; in research we designed the proportion mortar was used in compliance with 14 TCN 80-2001 and TCXD 2000 - Building standard [4, 5].

The compressive strength of mortar is calculated by following Eq. (1)

$$
f_{v}^{\prime}=A \cdot f_{c}^{\prime}\left(\frac{C}{W}-0.8\right)
$$

where: $A$ expresses materials quality, $A=1.05$ for materials of good quality, $A=0.90$ for materials of normal quality, and $A=0.75$ for materials of low quality. $f_{v}^{\prime}$ is the required compressive strength of mortar, $f_{c}^{\prime}$ is the compressive strength of cement, $C$ and $W$ are respectively the amount of cement and water in $1 \mathrm{~m}^{3}$ of the mortar.

The cement content is calculated by Eq. (2)

$$
C=\frac{1000}{\frac{1}{\rho_{c}}+\frac{W}{C}+\frac{n}{\rho_{s}}}
$$

where: $\rho_{c}, \rho_{s}$ are respectively the bulk specific gravity on oven-dry basis of cement and sand, $n$ is the sand to cement ratio by weight, $n=\frac{1}{(C / S)} ; S$ is the sand content in $1 \mathrm{~m}^{3}$ mortar, (C/S) can be chosen in graph of appendix A.2 of the standard branch 14TCN 80-2001.

Then we can calculate the proportion of mortar as follows:

$$
1: S / C: W / C=1: 3.0: 0.50
$$

In other hand, the high range water reducing admixture and polymer acrylic are used with the amount of $0.2-0.3 \%$ and $2-3 \%$, respectively.

\subsection{The experimental scheme method}

In this project, we used the experimental scheme method with the orthogonal central turn of two levels and two factors to aim building the statistical mathematics model, based on that to access the effects of factors on the properties of mortar; such as the plasticity, compressive strength, flexural strength, adhesion between the old concrete and new mortar, saturated absorption; thence finding the optimal percent of polymer and HRWR. of real variables and coded variables are presented in Table 3. 
Table 3. The experimental scheme

\begin{tabular}{|c|c|c|c|c|}
\hline \multirow{2}{*}{$N^{\circ}$} & \multicolumn{2}{|c|}{ Coded variables } & \multicolumn{2}{c|}{ Real variables } \\
\cline { 2 - 5 } & $\mathrm{X}_{1}$ & $\mathrm{X}_{2}$ & $\xi_{1}(\%)$ & $\xi_{2}(\%)$ \\
\hline 1 & 1 & -1 & 0.30 & 1 \\
\hline 2 & -1 & -1 & 0.20 & 1 \\
\hline 3 & -1 & 1 & 0.20 & 3 \\
\hline 4 & 1 & 1 & 0.30 & 3 \\
\hline 5 & 0 & 0 & 0.25 & 2 \\
\hline 6 & 1.414 & 0 & 0.37 & 2 \\
\hline 7 & 0 & -1.414 & 0.25 & 2 \\
\hline 8 & -1.414 & 0 & 0.18 & 3.6 \\
\hline 9 & 0 & 1.414 & 0.25 & 2 \\
\hline 10 & 0 & 0 & 0.25 & 2 \\
\hline 11 & 0 & 0 & 0.25 & 2 \\
\hline 12 & 0 & 0 & 0.25 & 2.6 \\
\hline
\end{tabular}

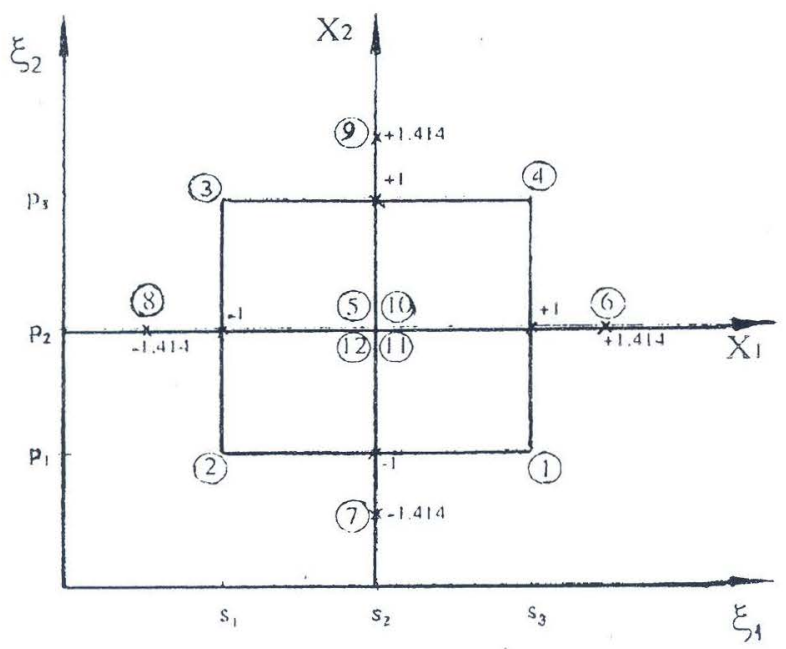

Fig. 1. Sketch of the experimental scheme method with the orthogonal central turn of two levels and two factors

In the experimental scheme method with two levels and two factors, as signed the percent of HRWR (\% of cement content) is $\xi_{1}$ and the percent of polymer (\% of cement content) is $\xi_{2}$. For establishing the experimental scheme the real variables $\xi_{1}$ and $\xi_{2}$ are encoded to become the coded variables $X_{1}$ and $X_{2}$ (see [6]). The value of the coded variables are chosen in the range of $(-1)$ and $(+1)$, at the centre point of experimental scheme (0), and the values on the axis $X_{1}$ and $X_{2}(+\infty,-\infty)$ to make the rotation of the orthogonal scheme central turn. The sketch of the experimental scheme method with two levels and two factors as shown in Fig. 1 and the scheme 


\subsection{Research diagram}

To research the effects of the admixture on some properties of mortar, we issue the diagram for experiments. The diagram is shown below.

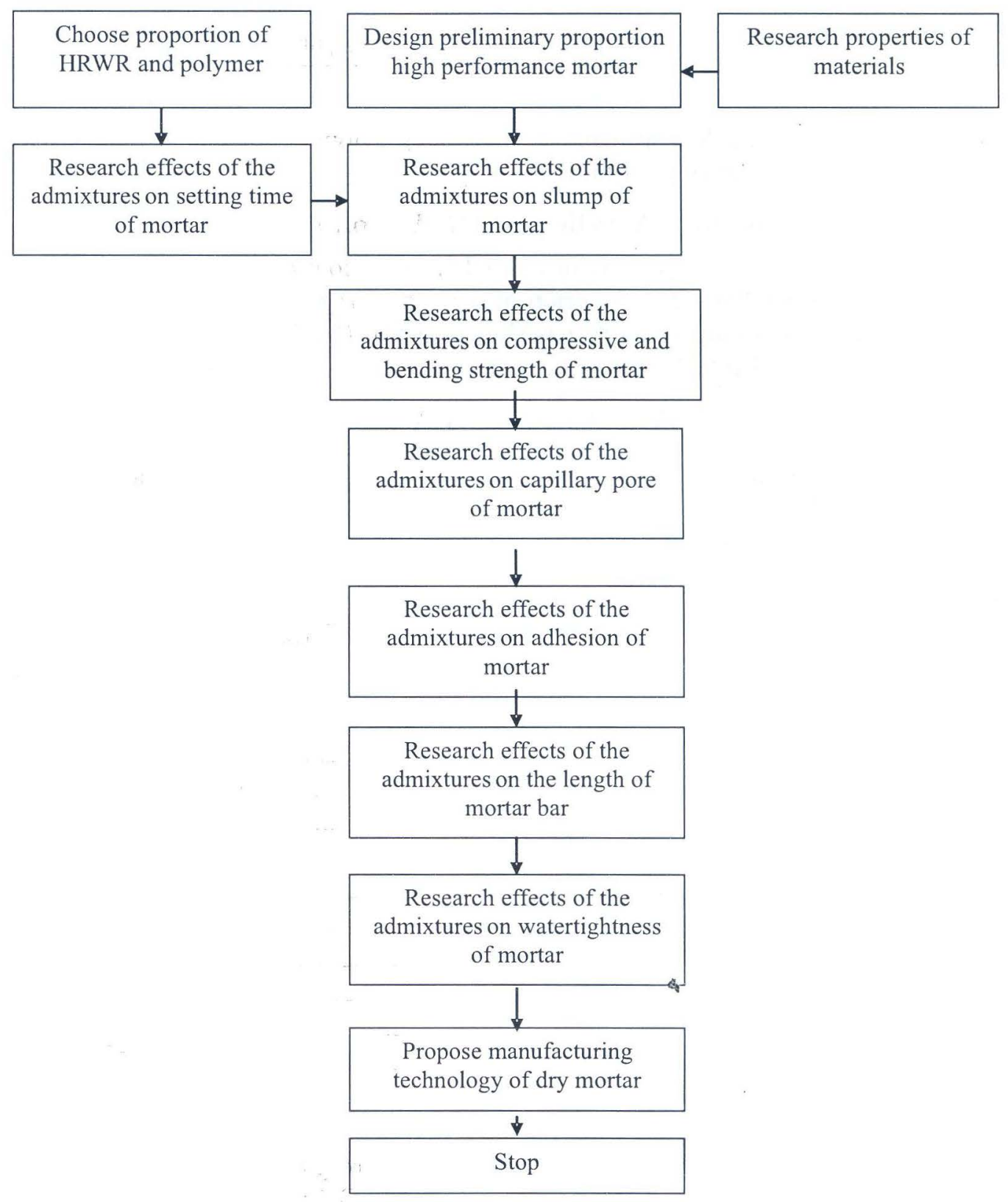

\section{RESULTS AND DISCUSSIONS}

\subsection{The effects of Polymer Acrylic on setting time of mortar}

The setting time of mortar with $0 \%, 1 \%, 2 \%$, and $3 \%$ percentage of Polymer Acrylic are shown in Table 4, respectively. 
Table 4. The results of setting time of mortar

\begin{tabular}{|l|l|l|l|l|}
\hline \% Acrylic & $\mathbf{0}$ & $\mathbf{1}$ & $\mathbf{2}$ & $\mathbf{3}$ \\
\hline Setting time (minutes) & & & & \\
Initial & 113 & 118 & 125 & 115 \\
Final & 190 & 198 & 195 & 196 \\
\hline
\end{tabular}

From the results in Table 4 we can see that using Polymer Acrylic of percentage (1-3 $\%$ ) didn't affect the setting time of mortar.

\subsection{The effects of Polymer Acrylic and HRWR on slump of mortar}

The slump of the mortar $\left(D_{2}\right)$ is measured by the flow of mortar on shaking table according to $14 \mathrm{TCN}$ 80-2001. The function of regression represents the effects of polymer Acrylic and HRWR on slump of mortar is shown in Eq. (3). The results of flat diameter of mortar are shown in Table 5.

$$
D_{2}=158.75+2.32 X_{1}-2.97 X_{2}-4.31 X_{1}^{2}+0.69 X_{2}^{2}-4.75 X_{1} X_{2},
$$

where: $D_{2}$ is the flat diameter of mortar; $X_{1}$ and $X_{2}$ are the coded variables.

Table 5. The flat diameter of mortar specimens

\begin{tabular}{|c|c|c|}
\hline $\mathbf{N}^{\mathbf{O}}$ & $\mathbf{D}_{2}(\mathbf{m m})$ & $\%$ \\
\hline Control & 190 & 100 \\
\hline 1 & 163 & 86 \\
\hline 2 & 152 & 80 \\
\hline 3 & 156 & 82 \\
\hline 4 & 148 & 78 \\
\hline 5 & 161 & 85 \\
\hline 6 & 156 & 82 \\
\hline 7 & 165 & 87 \\
\hline 8 & 145 & 76 \\
\hline 9 & 156 & 82 \\
\hline 10 & 164 & 86 \\
\hline 11 & 158 & 83 \\
\hline 12 & 152 & 80 \\
\hline
\end{tabular}

Note: The flat diameter of mortar with the presence of polymer and HRWR is less than the control specimen (about 13\% to 24\%) but they ensure good slump for application in Vietnamese climate condition and the accordance in 14TCN 80-2001.

\subsection{The effects of the admixtures on compressive strength of mortar}

The mortar specimens are moulded in prismatic mould with $160 \mathrm{~mm}$ length and $40 \times 40$ $\mathrm{mm}$ cross section. After 24 hours, they are demoulded and cured in the curing room at humidity $80 \%$ and temperature $25 \pm 2^{\circ} \mathrm{C}$. The specimens are tested to determine compressive strength and flexural strength at ages of 3,7 , and 28 days. 
The compressive strength of mortar of 3, 7 and 28 day-ages are shown in Table 6 . The compressive strength of mortar are represented by Eq. (4), (5) and (6)

$$
\begin{aligned}
& f_{c, 3}^{\prime}=32.535-0.575 X_{1}+0.707 X_{2}+0.297 X_{1}^{2}-0.803 X_{2}^{2}+0.277 X_{1} X_{2}, \\
& f_{c, 7}^{\prime}=35.534+0.417 X_{1}+0.119 X_{2}+1.166 X_{1}^{2}+1.982 X_{2}^{2}+0.893 X_{1} X_{2}, \\
& f_{c, 28}^{\prime}=43.937-0.436 X_{1}+0.997 X_{2}+1.044 X_{1}^{2}-0.329 X_{2}^{2}+1.723 X_{1} X_{2},
\end{aligned}
$$

where: $f_{c, 3}^{\prime}, f_{c, 7}^{\prime}, f_{c, 28}^{\prime}$ is the compressive strength of mortar at 3,7 and 28 days; $X_{1}$ and $X_{2}$ are the coded variables

Table 6. The compressive strength of mortar at given ages

\begin{tabular}{|c|c|c|c|c|c|c|}
\hline \multirow{2}{*}{$\mathbf{N}^{o}$} & \multicolumn{2}{|c|}{ 3 days } & \multicolumn{2}{c|}{$\mathbf{7}$ days } & \multicolumn{2}{c|}{ 28 days } \\
\cline { 2 - 7 } & $f_{c, 3}^{\prime}(\mathrm{MPa})$ & $\%$ & $f_{c, 7}^{\prime}(\mathrm{MPa})$ & $\%$ & $f_{c, 28}^{\prime}(\mathrm{MPa})$ & $\%$ \\
\hline Control & 30.1 & 100 & 35.1 & 100 & 43.7 & 100 \\
\hline 1 & 29.3 & 97 & 35.3 & 101 & 40.3 & 92 \\
\hline 2 & 32.0 & 106 & 37.3 & 106 & 43.8 & 100 \\
\hline 3 & 33.4 & 111 & 36.8 & 105 & 44.3 & 101 \\
\hline 4 & 31.9 & 106 & 38.4 & 110 & 47.7 & 109 \\
\hline 5 & 32.8 & 109 & 36.4 & 104 & 47.9 & 110 \\
\hline 6 & 33.5 & 111 & 40.9 & 117 & 45.5 & 104 \\
\hline 7 & 30.8 & 102 & 41.8 & 119 & 43.9 & 100 \\
\hline 8 & 33.7 & 112 & 38.2 & 109 & 47.9 & 110 \\
\hline 9 & 32.0 & 106 & 40.6 & 116 & 44.0 & 101 \\
\hline 10 & 31.6 & 105 & 35.7 & 102 & 42.8 & 98 \\
\hline 33.1 & 110 & 38.2 & 109 & 45.4 & 104 & \\
\hline 12 & 32.9 & 109 & 31.9 & 91 & 39.7 & 91 \\
\hline
\end{tabular}

Note: From the results of compressive strength (see Table 6) we can see that the presence of polymer and HRWR doesn't affect on the compressive strength, and after 28 days the difference of compressive strengths of these mortars is negligible. With $W / C=$ 0.5, the compressive strength of mortar is usually more than $40 \mathrm{MPa}$. However, when the admixtures content is high, the compressive strength of mortar attains $47.7 \mathrm{MPa}$, higher than control mix about $9 \%$.

\subsection{The effects of the admixtures on flexural strength of mortar}

The flexural strength of mortar at the given ages is shown in Table 7.

The effects of the admixtures on the flexural strength of mortar are represented by Eq. (7), (8) and (9):

$$
\begin{aligned}
& f_{b, 3}^{\prime}=7.772-0.195 X_{1}-0.261 X_{2}+0.146 X_{1}^{2}-0.389 X_{2}^{2}-0.267 X_{1} X_{2} \\
& f_{b, 7}^{\prime}=8.361-0.016 X_{1}+0.222 X_{2}+0.547 X_{1}^{2}+0.067 X_{2}^{2}+0.117 X_{1} X_{2} \\
& f_{b, 28}^{\prime}=8.788-0.071 X_{1}+0.333 X_{2}+0.416 X_{1}^{2}+0.023 X_{2}^{2}-X_{1} X_{2}
\end{aligned}
$$

where: $f_{b, 3}^{\prime}, f_{b, 7}^{\prime}, f_{b, 28}^{\prime}$ is the flexural strength of mortar at 3,7 . and 28 days; $X_{1}$ and $X_{2}$ are the coded variables. 
Table \%. The flexural strength of mortar at given ages

\begin{tabular}{|c|c|c|c|c|c|c|}
\hline \multirow{2}{*}{$\mathbf{N}^{o}$} & \multicolumn{2}{|c|}{$\mathbf{3}$ days } & \multicolumn{2}{c|}{$\mathbf{7}$ days } & \multicolumn{2}{c|}{ 28 days } \\
\cline { 2 - 7 } & $f_{b, 3}^{\prime}(M P a)$ & $\%$ & $f_{b, 7}^{\prime}(M P a)$ & $\%$ & $f_{b, 28}^{\prime}(M P a)$ & $\%$ \\
\hline Control & 6.7 & 100 & 8.0 & 100 & 10.12 & 100 \\
\hline 1 & 7.5 & 112 & 8.8 & 111 & 8.14 & 80 \\
\hline 2 & 8.5 & 127 & 8.7 & 109 & 9.14 & 90 \\
\hline 3 & 8.6 & 128 & 8.2 & 103 & 9.77 & 97 \\
\hline 4 & 6.5 & 97 & 8.9 & 111 & 9.27 & 92 \\
\hline 5 & 6.9 & 103 & 8.2 & 102 & 8.75 & 87 \\
\hline 6 & 8.4 & 125 & 9.4 & 118 & 9.56 & 94 \\
\hline 7 & 7.3 & 109 & 8.1 & 101 & 8.12 & 80 \\
\hline 8 & 7.3 & 109 & 10.1 & 127 & 9.53 & 94 \\
\hline 9 & 6.5 & 96 & 9.6 & 120 & 9.40 & 93 \\
\hline 10 & 7.8 & 116 & 8.8 & 110 & 8.91 & 88 \\
\hline 11 & 8.7 & 130 & 8.4 & 105 & 9.06 & 90 \\
\hline 12 & 7.9 & 114 & 8.1 & 102 & 8.42 & 83 \\
\hline
\end{tabular}

Note: Compared with control specimen, the flexural strength at 28 days of specimen containing polymer and HRWR are little lower, (about $90 \%$ of flexural strength of the control specimen). This reason is the effects of polymer on the structure of cement matrix. However, increasing the density and decreasing the capillary pore of mortar to increase watertightness is aimed, so that the suitable percent of admixtures is necessary to use.

\subsection{The effects of the admixtures on the adhered strength to parent mortar of mortar}

The adhesion of mortar to parent mortar at 28 days as shown in Table 8.

Table 8. The adhered strength of mortar at 28 days

\begin{tabular}{|c|c|c|}
\hline \multirow{2}{*}{$\mathbf{N}^{\circ}$} & \multicolumn{2}{|c|}{$\mathbf{2 8}$ days } \\
\cline { 2 - 3 } & $f_{a, 28}^{\prime}(\mathrm{MPa})$ & $\%$ \\
\hline Control & 4.3 & 100 \\
\hline 1 & 4.8 & 109 \\
\hline 2 & 5.2 & 120 \\
\hline 3 & 5.7 & 132 \\
\hline 4 & 6.6 & 152 \\
\hline 5 & 6.4 & 147 \\
\hline 6 & 4.3 & 99 \\
\hline 7 & 5.1 & 118 \\
\hline 8 & 6.2 & 142 \\
\hline 9 & 4.9 & 112 \\
\hline 10 & 6.8 & 157 \\
\hline 11 & 4.8 & 111 \\
\hline 12 & 5.7 & 132 \\
\hline
\end{tabular}


The effects of the admixtures on the adhesion of mortar is shown by Eq.(10):

$$
f_{a, 28}^{\prime}=5.933-0.279 X_{1}+0.274 X_{2}-0.229 X_{1}^{2}-0.037 X_{2}^{2}-0.332 X_{1} X_{2}
$$

where: $f_{a, 28}^{\prime}$ is the adhesion strength of mortar at 28 days; $X_{1}$ and $X_{2}$ are the coded variables

Note: Using polymer and HRWR in mixed mortar increases the adhesion strength of mortar (about 10\% to 57\%) (see Table 8). We can see that, with the proportion of high range water reducing is $0.225 \%$ and polymer is $2.5 \%$, the adhesion strength is $6.6 \mathrm{MPa}$, that is higher than $52 \%$ comparing with control specimen.

\subsection{The compressive strength of mortar on compacted sub-grade}

The compressive strength of mortar on compacted sub-grade at the given ages $(3,7$ and 28 days) is shown in Table 9.

Table 9. The compressive strength of mortar at given ages

\begin{tabular}{|c|c|c|c|c|c|c|}
\hline \multirow{2}{*}{$\mathbf{N}^{\circ}$} & \multicolumn{2}{|c|}{3 days } & \multicolumn{2}{c|}{7 days } & \multicolumn{2}{c|}{ 28 days } \\
\cline { 2 - 7 } & $f_{c, 3}^{\prime}(M P a)$ & $\%$ & $f_{c, 7}^{\prime}(M P a)$ & $\%$ & $f_{c, 28}^{\prime}(M P a)$ & $\%$ \\
\hline Control & 18.0 & 100 & 34.5 & 100 & 41.0 & 100 \\
\hline 1 & 18.2 & 101 & 29.5 & 86 & 38.9 & 95 \\
\hline 2 & 23.4 & 130 & 32.2 & 93 & 36.3 & 89 \\
\hline 3 & 24.4 & 135 & 34.8 & 101 & 39.2 & 96 \\
\hline 4 & 21.2 & 118 & 30.7 & 89 & 40.1 & 98 \\
\hline 5 & 26.6 & 148 & 30.0 & 87 & 37.7 & 92 \\
\hline 6 & 21.7 & 121 & 29.8 & 86 & 36.0 & 88 \\
\hline 7 & 26.9 & 149 & 30.1 & 87 & 37.0 & 90 \\
\hline 8 & 22.3 & 124 & 34.1 & 99 & 41.0 & 100 \\
\hline 9 & 26.0 & 145 & 36.6 & 106 & 46.2 & 113 \\
\hline 10 & 27.3 & 152 & 31.5 & 91 & 38.5 & 94 \\
\hline 11 & 19.9 & 111 & 32.1 & 93 & 40.2 & 98 \\
\hline 12 & 23.0 & 128 & 27.8 & 81 & 37.6 & 92 \\
\hline
\end{tabular}

The effects of the admixtures on the compressive strength of mortar on compacted sub-grade are represented by Eq. (11), (12) and (13):

$$
\begin{gathered}
f_{c, 3}^{\prime}=24.217-1.142 X_{1}+0.353 X_{2}-1.721 X_{1}^{2}+0.513 X_{2}^{2}+0.517 X_{1} X_{2} \\
f_{c, 7}^{\prime}=30.11-1.624 X_{1}+1.622 X_{2}+0.721 X_{1}^{2}+1.404 X_{2}^{2}-0.367 X_{1} X_{2} \\
f_{c, 28}^{\prime}=37.834-0.356 X_{1}+0.143 X_{2}+0.104 X_{1}^{2}+1.487 X_{2}^{2}-0.4 X_{1} X_{2}
\end{gathered}
$$

where: $f_{c, 3}^{\prime}, f_{c, 7}^{\prime}, f_{c, 28}^{\prime}$ are the compressive strength of mortar on compacted sub-grade at 3, 7 and 28 days; $X_{1}$ and $X_{2}$ are the coded variables

Note: Polymer and HRWR affect little on the compressive strength of mortar on compacted sub-grade as prescribed in TCVN (Vietnamese standard). The compressive strength is more than $30 \mathrm{MPa}$ at 28 days, that can reach the target in the project. We can see that the range of HRWR content from $0.2 \%$ to $0.3 \%$ doesn't influence on compressive 
strength on compacted sub-grade. So that the water to cement ratio chose, $(W / C=0.50)$ is suitable.

\subsection{The effects of the admixtures on capillary pore and saturated absorption of mortar}

The capillary pore and saturation absorption of mortar are given in Table 10

Table 10. The capillary pore and saturated absorption of mortar

\begin{tabular}{|c|c|c|c|c|}
\hline \multirow{2}{*}{$\mathbf{N}^{o}$} & $\mathbf{W T}_{\text {dry }}$ & $\mathbf{W T}_{\text {saturated }}$ & $\frac{W T_{\text {saturated }}-W T_{\text {dry }}}{W T_{\text {dry }}} 100$ & Capillary pore \\
\cline { 2 - 5 } & $(g)$ & $(g)$ & $\%$ & $\%$ \\
\hline Control & 570.2 & 591.0 & 3.65 & 8.2 \\
\hline 1 & 567.0 & 582.7 & 2.77 & 6.2 \\
\hline 2 & 563.2 & 577.7 & 2.57 & 5.8 \\
\hline 3 & 577.3 & 589.5 & 2.11 & 4.8 \\
\hline 4 & 553.7 & 568.5 & 2.67 & 6.0 \\
\hline 5 & 566.8 & 583.0 & 2.86 & 6.4 \\
\hline 6 & 571.7 & 583.5 & 2.06 & 4.6 \\
\hline 7 & 575.2 & 588.8 & 2.36 & 5.3 \\
\hline 8 & 546.2 & 561.0 & 2.71 & 6.1 \\
\hline 9 & 553.7 & 566.8 & 2.37 & 5.3 \\
\hline 10 & 552.7 & 564.3 & 2.10 & 4.7 \\
\hline 11 & 554.8 & 570.2 & 2.78 & 6.3 \\
\hline 12 & 564.7 & 577.3 & 2.23 & 5.0 \\
\hline
\end{tabular}

Note: $W T_{\text {dry }}, W T_{\text {saturated }}$ are weight of dry and saturated specimens, respectively.

The effects of the admixtures on the saturation absorption of mortar are represented by Eq. (14)

$$
D_{s}=2.49-0.02 X_{1}-0.07 X_{2}-0.02 X_{1}^{2}-0.03 X_{2}^{2}+0.09 X_{1} X_{2}
$$

where: $D_{s}$ is the saturation absorption of mortar; $X_{1}$ and $X_{2}$ are the coded variables

Note: In comparison with the control specimen, the capillary pore of specimens with admixtures is lower about $20 \%$ to $40 \%$. Therefore the presence of polymer and HRWR in mixed mortar increases its watertightness (see Table 10).

\subsection{The effects of the admixtures on the length change of mortar bar}

The length change of mortar bar is measured in compliance with [7]. The specimens are casted and cured in the humidity of $80 \%$ and temperature of $25 \pm 2^{\circ} \mathrm{C}$ (condition in Vietnam). Symbol $M_{0}$ relates to specimen without admixtures; $M_{1}$ relates to specimen containing 3\% polymer acrylic and $0.3 \%$ HRWR. The results of the length change of mortar bar for some given ages are represented in Table 11 and Fig. 2.

After 28 days, the shrinkage of control mortar $\left(\mathrm{M}_{o}\right)$ is $0.41 \%$; this result is complied with some other research results $[8,9,10]$. In that time, the specimen containing $3 \%$ polymer acrylic and $0.3 \%$ HRWR $\left(M_{1}\right)$ has the shrinkage of $0.06 \%$ that is very small. Thus, the adhesion to parent mortar of the mortar containing admixtures (polymer and HRWR) is higher than that of the mortar without admixtures. So that, the polymer acrylic 
Table 11. The length change of mortar

\begin{tabular}{|c|c|c|}
\hline \multirow{2}{*}{ Given ages } & \multicolumn{2}{|c|}{ Length change $\Delta \boldsymbol{L x}(\%)$} \\
\cline { 2 - 3 } & $M_{0}$ & $\boldsymbol{M}_{1}$ \\
\hline 1 & -0.3235 & -0.0115 \\
\hline 2 & -0.3626 & -0.0241 \\
\hline 3 & -0.3722 & -0.0286 \\
\hline 7 & -0.3757 & -0.0469 \\
\hline 14 & -0.3931 & -0.0503 \\
\hline 21 & -0.4052 & -0.0559 \\
\hline 28 & -0.4087 & -0.0628 \\
\hline
\end{tabular}

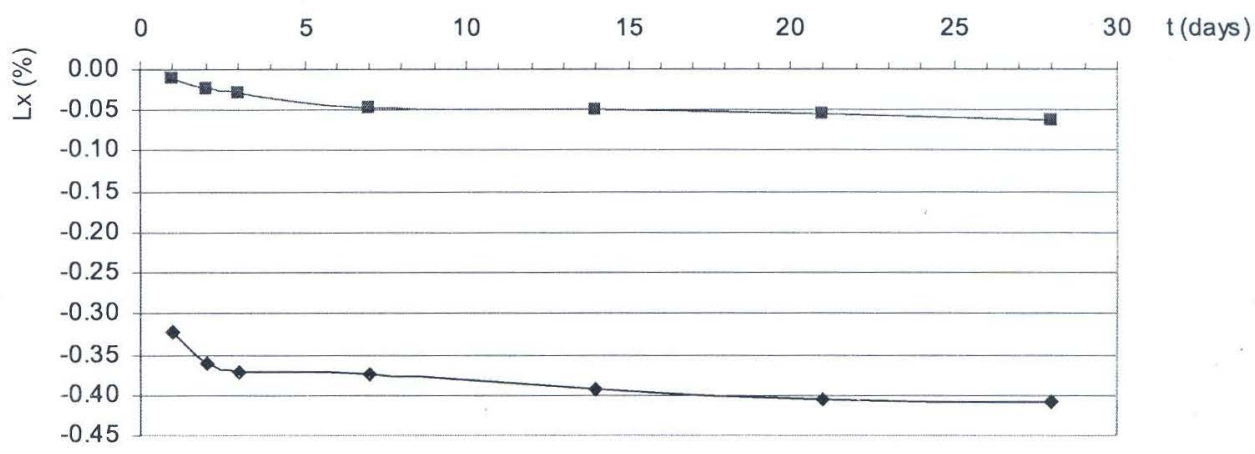

$\rightarrow$ Mo-0\%Acr, 0\%HRWR $\rightarrow$ M1-3\%Acr, 0.3\%HRWR

Fig. 2. The length change of mortar bar

and HRWR are important for the manufacturing mixed mortar having high compressive strength and low shrinkage.

\subsection{The results of watertightness of mortar}

The watertightness of mixed mortar is tested as prescribed in [4]. Prismatic mortar specimens with $150 \times 150 \mathrm{~mm}$ cross section and 30,40 , and $70 \mathrm{~mm}$ thickness are prepared for measurements watertightness. After 28 curing days in standard condition, the specimens are tested on the Matest machine with $0.4 \mathrm{MPa} / \mathrm{cm}^{2}$ pressure. To maintain the time for specimens in 24 hours for $30 \mathrm{~mm}$ thickness, 48 hours for $40 \mathrm{~mm}$ thickness, and 78 hours for $70 \mathrm{~mm}$ thickness; the specimens are not permeable. So that, the mixed mortar has high watertightness.

\section{PUT FORWARD THE CHART FOR MANUFACTURING TECHNOLOGY AND CONCLUSION}

\subsection{Issue chart for manufacturing technology}

Dry mortar is packed the cement bag, each bag weight $15 \pm 0.5 \mathrm{~kg}$. 
The proportion of mortar by weight is C $: \mathrm{S}:$ Polymer : HRWR $=1: 3: 0.03: 0.003$. The chart for manufacturing technology of dry mixed mortar as shown below

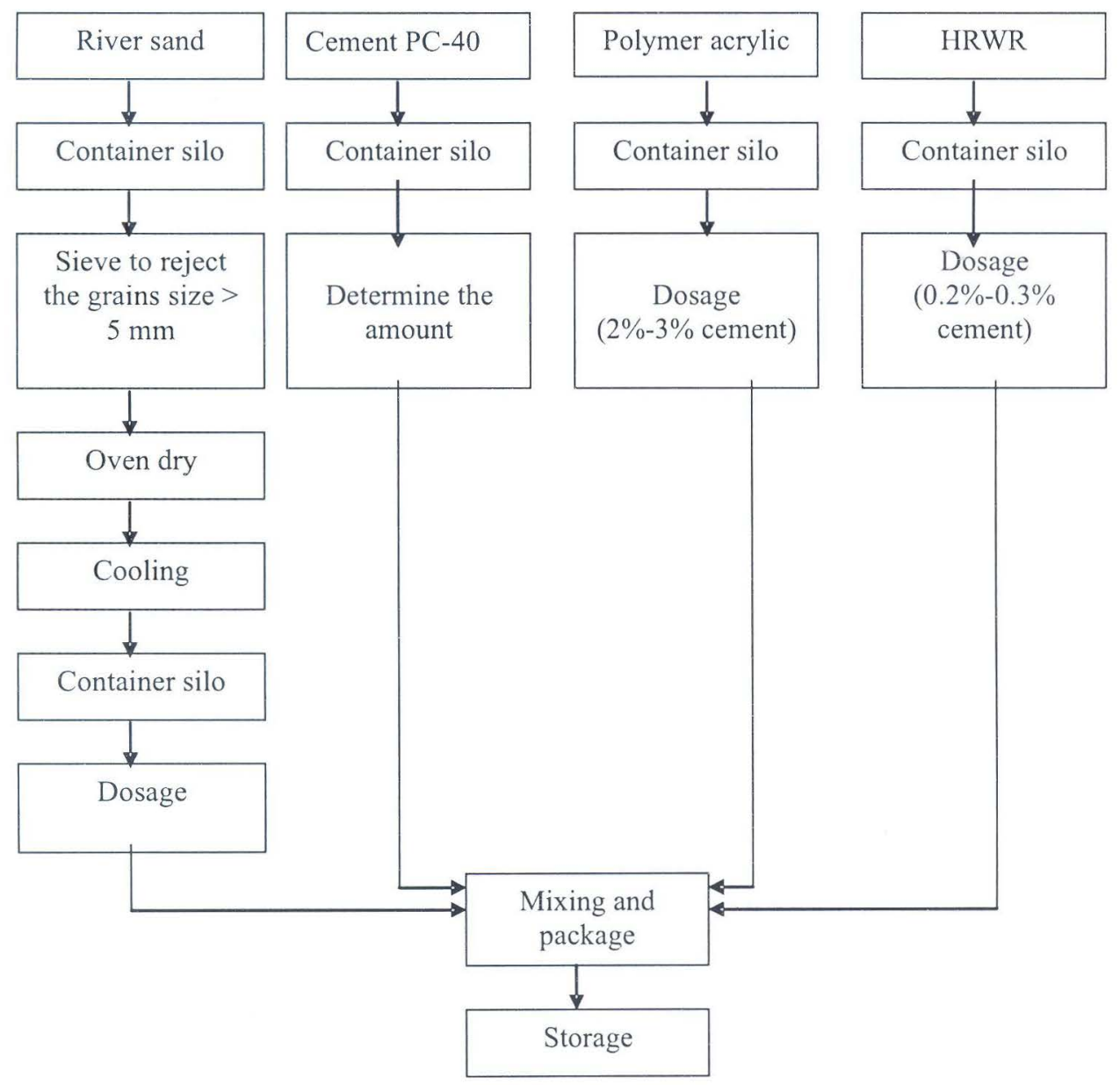

\subsection{Main conclusions}

1. The presence of polymer and high range water reducing admixture with researched range don't affect the setting time and workability of mortar.

2 . With water to cement ratio $W / C=0.5$, the compressive strength of mortar is more than $40 \mathrm{MPa}$. It is suitable for high strength mortar for restoration of hydraulic structures.

3. The presence of polymer and high range water reducing, exercises small the influence to flexural strength, the compressive of mortar on the compacted sub-grade.

4. The mortar with polymer and high range water reducing admixture increase the adhesion strength and watertightness of mortar.

\section{REFERENCES}

1. Duong Duc Tin, Le Minh, Research to manufacture and use poly-molecule materials spray for the restoration of hydraulic structures; a project of Building Material Science Department, Institute of Water Resources Research, 1996. 
2. Proceeding of Vietnam Construction Standards, Building Standards 1770. Building Sand Technical Requirements, Construction Publisher, Hanoi 1997.

3. Ministry of Agriculture and Rural Development: Standard branch $14 T C N$ 80, Hydraulic Mortar - Technical Requirements and Testing Method, Central Information of Agriculture and Rural Development Publisher, Hanoi 2002.

4. Proceeding of Vietnam Construction Standards, Building Standards 2000. Dry cement mortar no shrinkage - Technical requirements and Testing method, Ministry of Construction, Construction Publisher, Hanoi 2000.

5. V. I. Malin, Proportions of dry mortar for construction, Doctor dissertation, 1986.

6. American Society for Testing and Materials (ASTM) Committee C09, 2003b. Standards Test Method for Length Change of Hardened Hydraulic-Cement Mortar and Concrete (ASTM C 157/C 157M-03), West Conshohocken: ASTM International.

7. L. Czarnecki and P. Lukowski, Optimization of Polymer cement concretes, Optimization methods for material design of cement-based composites (ed. A.M.Brandt), Modern Concrete Technology 7, E \& FN Spon, London and New York, 1998, pp. 231-250.

8. E. Sakai and J. Sugita, Composite Mechanism of Polymer Modified Cement, Cement and Concrete Research 25 (1) (1995) 127-135.

9. S. Chandra, Polymer Cement Composite - a Critical Review, Advanced in Cement and Concrete, American Society of Civil Engineers, 1994, pp. 15-36.

Received July 29, 2008

\section{NGHIÊN CỨU SẢN XUẤT VŨ̃A KHÔ TRỘN SÃ̃N CÓ CƯờNG Độ NÉN VÀ CƯờNG DỘ UỐN CAO, CO NGÓT THẤP VÀ CHỐNG THẤM TỔT DÙNG TRONG SỬA CHŨ̃A HU' HỎNG CÁC CÔNG TRÌNH THỦY LợI CỦA VIẸTT NAM}

Sử dụng các vật liệu thông thường để sản xuất vữa trộn sẵn là rất cần thiết cho sửa chữa các công trình thủy lợi ở Việt Nam. Nó sẽ tiết kiệm được vật liệu và giảm giá thành của vữa. Trong nghiên cứu này, chúng tôi đã sử dụng xi măng sản xuất tại Việt Nam (xi măng Chinfon-Hải Phòng), cát tự nhiên (cát sông Lô), polymer Acrylic và phụ gia giảm nước bậc cao của công ty SIKA với tỷ lệ: 1 : 3 : 0.03 : 0.003 theo khối lượng. Tỷ lệ nước/xi măng là 0.5 luôn luôn dảm bảo cường độ nén của vữa lớn hơn $40 \mathrm{MPa}$, vữa có độ co ngót thấp, chống thấm tốt và độ dính kết cao. Vữa đó phù hợp cho sửa chữa các công trình bê tông nói chung và các công trình thủy lợi nói riêng của Việt Nam. Vữa khô trộn sẵn được sản xuất và đóng bao với khối lượng $15 \pm 0.5 \mathrm{~kg}$. 